\title{
KARAKTERISTIK PENDIDIKAN DALAM TINJAUAN AL-QUR'AN DAN AS-SUNNAH
}

\author{
Muhammad Firdaus* \\ Fitriana Rusyai Ali* \\ muhammad.firdaus@umt.ac.id*, fitriana@umt.ac.id** \\ *Dosen Fakultas Agama Islam, Universitas Muhammadiyah Tangerang \\ *Dosen Magister Pendidikan Agama Islam, Universitas Muhammadiyah Tangerang
}

\begin{abstract}
The flow of globalization is rolling along with the times. Islamic education has the responsibility of equipping people. Through Islamic education, humans can be directed to good morals, and are open to receive good influence from outside, as well as selfdevelopment from within with a foundation of faith and piety to Allah SWT, however, if a negative influence cannot be avoided. Then there will be circles of Muslims who understand Islamic teachings imperfectly, both from the methods and values of education in Islam, which in turn they are oriented to the teachings, methods, values of thought that contrary to Islamic teachings. Therefore, a discussion that explains the characteristics of education in the review of the Qur'an and Sunnah is needed. It is to face the problems faced by Muslims in implementing Islamic education. Which it is by the teachings of Islam comprehensively sourced from the Qur'an, As-Sunnah, and the thought of Islamic scholars. This method has been applied for centuries before Western methods and thought, an education that maintains the originality of Islamic teachings.
\end{abstract}

Keywords: Characteristics, Education, Al-Qur'an and As-Sunnah

\section{A. PENDAHULUAN}

Islam adalah agama yang sangat memperhatikan pendidikan. Tujuan syariat Islam itu sendiri adalah untuk menjunjung tinggi nilai-nilai kemanusian, menjaga serta memuliakan harkat dan martabat manusia sebagai makhuk yang berakal, untuk itu tidak ada suatu pedoman yang lebih baik dalam mewujudkan itu semua kecuali apa yang telah Allah subhãnahu wata'âlã gambarkan dalam Al-Qur'an dan realisasinya dalam kehidupan nyata sebagaimana di contohkan oleh Nabi Muhammad Shallãhu a'lahi wasallam baik berupa pernyataan, perkataan dan perbuatannya.

Al-Qur'an adalah pedoman dan petunjuk bagi manusia, yang mana disetiap perintah dan larangan yang terdapat pada ayat-ayatnya mampu membentuk kepribadian manusia yang luhur dan mulia, ayat-ayatnya terpatri kuat dalam hati setiap hamba yang beriman, karena ia meyakini bahwa semua itu bersumber dari sisi Allah subhãnahu wata'ãlã, hamba yang mampu mengambil setiap pelajaran dari padanya.

Pendidikan dalam Islam sangat berkaitan dengan akidah dan akhlak. Pendidikan merupakan proses penyempurnaan nilai-nilai penghambaan seseorang kepada tuhannya, menanamkan pemahaman antara hak dan kewajiban dalam interaksi sosial dan memperbaiki moral. Maka, pendidikan adalah suatu aktivitas yang mengukuhkan nilai-nila akidah, ibadah dan ketetapan terhadap perbuatan mukallaf (orang yang di bebani syariat).

As-Sunnah merupakan pondasi dalam pendidikan, ianya merupakan sumber wahyu ke dua, bersumber dari setiap perkataan, perbuatan dan ketetapan Rasũlullãh Shallãhu 'alaihi wasallam, sebagaimana difirmankan dalam AlQur'an : 


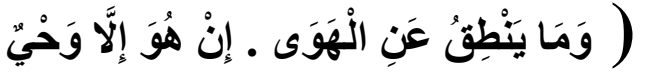

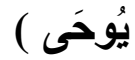

"Dan tidaklah yang di ucapkannya itu menurut kemauan hawa nafsunya.Ucapannya itu ialah wahyu yang di wahyukan kepadanya”. (QS. An-Najm : $3-4)$.

Dan Allah subhãnahu wata'ãlã, menegaskan bahwasanya Rasũlullãh Shallãhu alaihi wasallam memiliki budi perkerti yang luhur.

$$
\text { ( وَإنَّلََ لَعَلَى خُلُقِ عَظِيمٍ ) }
$$

“Dan sesungguhnya kamu benarbenar berbudi pekerti yang agung”. (QS. Al-Qolam : 4).

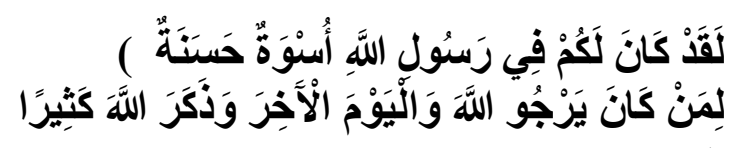

"Sesunggunya telah ada pada diri Rasũlullãh Shallãhu 'alaihi wasallam itu suri tauladan yang baik bagimu, yaitu bagi orang-orang yang mengharapkan rahmat Allah dan kedatangan hari kiamat, dan dia banyak menyebut Allah".(QS. Al-Ahzab : 21).

\section{B. PEMBAHASAN}

\section{Pengertian Mu'allim}

Unsur pertama dalam sebuah sistem pendidikan adalah guru atau pembimbing, istilah dalam Islam ialah al-mu'allim yaitu yang memberikan tanda, seperti ramburambu di setiap jalan atau pembatas. (Ibn Mandzũr. lisãn al-'arab. 12/ 416).

Seorangal-mu'allim dalam pendidikan Islam bukan sekedar pembimbing/al-musyrif atau al-muwajjih yaitu seseorang yang memiliki kemampuan untuk membuat perbedaan dalam proses pendidikan di sekolah dengan menggunakan wewenang yang diberikan kepadanya. (Abduh Faliyyah, Farũq. Abd Al-Fattãh, Ahmad, Mu'jam Mushthalahãt At-Tarbiyah lafdzan wa ishtilãhan. 242).

Melainkan Seseorang yang mampu melihat setiap kondisi, situasi dan keadaan pada proses pendidikan, lalu menyikapinya dengan sikap terbaik yang ia miliki sesuai dengan arahan dan bimbingan yang bersesuaian dangan syariat Islam yang mampu mempertajam kesadaran peserta didik dalam memahami setiap kebenaran dan kekeliruan yang terjadi di tengahtengah masyarakat, baik dalam bentuk kepercayaan/keyakinan maupun prilaku penyimpangan. (Nandhrot An-Na'ĩm fĩ makãrim akhlãq Ar-Rosũl Al-Karĩm. 1/ 162). Pernyataan ini sesuai dengan yang tertulis di dalam Al-Qur'an :

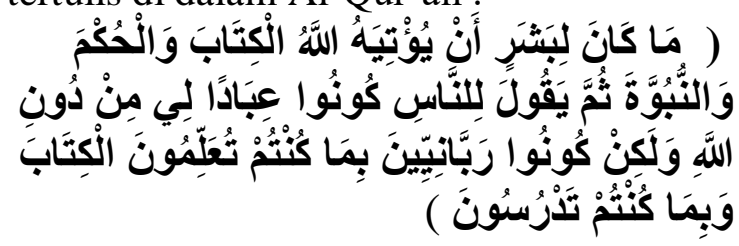

"Tidak mungkin bagi seseorang yang telah di beri kitab oleh Allah, serta hikmah dan kenabian, kemudian dia berkata kepada manusia "jadilah kamu penyembahku, bukan penyembah Allah", tetapi ia berkata "jadilah kamu pengabdipengabdi Allah, karena kamu mengajarkan kitab dan karena kamu mempelajarinya”.(QS. Ali 'Imran : 79).

Dalam hal ini, ada beberapa hal yang perlu diperhatikan oleh seorang mu'alim/guru, yaitu :

a. Menyadari betapa pentingnya fungsi guru dalam pengembangan nilai-nilai akhlak AlIslamiyah.

b. Memahami arahan AlQur'an dan As-Sunnah dalam pendidikan.

c. Memahami dan menguasai tema-tema yang akan ia ajarkan dan mengembangkannya demi terbentuknya individu-individu yang berkualitas dari segi keilmuan dan kepribadian.

d. Mampu berkomitmen dengan nilai-nilai yang ia ajarkan dan mampu menjadi contoh dalam setiap kondisi dan situasi yang di hadapi peserta didik, berpandu kepada akhlak Rosũlullãh Shallãhu 'alaihi wasallam. 
e. Mampu menjadi seorang pengajar yang mahir dalam suatu bidang keilmuan dengan mengedepankan metode yang sesuai dalam mengembangkan nilai-nilai akhlak melalui pengajaran suatu bidang spesialisasi atau disiplin keilmuan tertentu. (Ibid. Jilid 1. Hal 178)

\section{Pengertian Tarbiyah}

Pendidikan dalam Islam disebut dengan at-tarbiyah (التربية), maka secara terminologi kata at-tarbiyah memiliki tiga

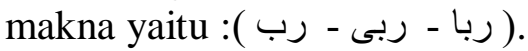

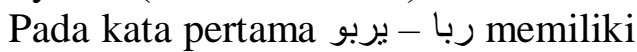
makna ينمو yang artiya mengayomi. Sedangkan pada kata yang ke dua - ربى يربى memiliki makna tumbuh dan berkembang. Sedangkan pada kata yang ke tiga رب - رب memiliki makna memperbaiki, bertanggung jawab dan memelihara. Ibn Mandzur berkata: رَََّّّ ) (الثيءُ يَرَبَ وَرُبُوُّا وَرِبَاء :bertambah sesuatu, tumbuh dan berkembang, bertanggung jawab dan memelihara. (Ibn Mandzũr.lisãn al-'arab.Jilid 14. Hal.304). Sebagaimana disebutkan dalam Al-Qur'an :

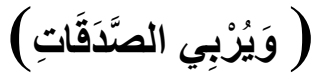

"Dan Allah SWT menyuburkan sedekah”.(QS. Al-Baqoroh : 276), yaitu : memperbanyak, menumbuhkan dan memeliharanya. (Ibn Katsir. tafsir alquran al-adz̃̃m.Jilid 1.Hal 714).

Berkata Al-Jauhariy :pada ayat diatas bermakna menumbuhkan, seperti halnya memelihara anak/keturunan, perkebunan dll. (Al-Jauhariy.Al-Shahhãh fĩ AlLughah.Jilid 6.Hal. 200)

Dijelaskan oleh Ibn Fãris bahwasanya kalimat Rabbun memiliki dua arti dasar, pertama yaitu:memberikan mashlahat dan melakukan perbaikan. Ianya juga berarti raja, pencipta, pendamping,majikan, bapak angkat/asuh, mengasuh. Seperti di ungkapkan dalam sebuah atsar arab mengenai Mujahid :

$$
\text { أنه كان يَكْرَه أن يتزوَّ جَ الرجلُ امر أَََ رابِّه }
$$

"Sesungguhnya ia (Mujahid) tidak menyukai seorang anak tiri menikahi ibu asuhnya (istri tuannya/majikannya)". (AlHarwiy Abu U'baid Al-Qōsim bin Salãm. Gharĩb Al-Hadĩts. Jilid 4.Hal 420).Arti dasar kedua:menjelaskan kebutuhan suatu hal yang memiliki sifat tetap dan berangsur-angsur dalam penerapanya. (Mufradãt Al-Rãghib AlAshbahaniy.Hal. 184)

Arti kalimat al-rabbu (الرب) dalam tarbiyah Islamiyah ialah suatu proses terhadap tahap pertumbuhan dan kelengkapan.(Ibn Fãris Abu Al-Husain Ahmad.Mu'jam Maqōyĩs Al-Lughah.2/ 313)

Menurut Abû al-A'lâ al-Maudûdî, kalimat al-rabbu (الرب) mengandung beberapa arti diantaranya : (1) mendidik, memelihara, dan meningkatkan, menghimpun,dan mempersiapkan, (3) tanggung jawab, perbaikan, dan pengasuhan, (4) keagungan, kepemimpinan, dan wewenang, pemilik.(Samsul Nizar dan Zainal Efendi Hasibuan, Hadis Tarbawi: Membangun Kerangka Pendidikan Ideal Perspektif Rasulullah, (Jakarta: Kalam Mulia, 2011/ 112.)

Sedangkan makna dasar pada kalimat al-rabbu (الرب) adalah at-tarbiyah (التربية) yang berarti menjelaskan kesempurnaan sesuatu secara bertahap, kemudian ianya di deskripsikan kepada Allah subhãnahu wata'ãlã sebagai sesuatu yang agung dan mulia. (. Al-Badhãwiy.AnWãru At-Tanzĩl wa Asrōru At-Ta'wĩl. 1/ 42).

Maka, dapat di simpulkan maknaattarbiyah (الثربية) ialah kalimat serapan dari (ربا) jika ianya bertambah, juga (نما) yaitu sesuatu yang terikat dengan memelihara sesuatu untuk meningkatkan, mengembangkan, memperkuat serta membawanya pada jalan kedewasaan dan kesempurnaan dengan menyesuaikan alam dan karakter kepribadiannya. (Muhammad Abd.Allah Darrãz. 1953.kalimãt fĩ mabãdi 'ilm al-akhlãq. 40). 


\section{Unsur-unsur yang mesti terpenuhi dalam tarbiyah Islamiyah}

Ada beberapa unsur yang perlu diperhatikan dalam tarbiyah Islamiyah, diantaranya ialah :

1. Menjaga kemurnian fitrah peserta didik dan peduli terhadap komitmen mereka dalam pendidikan dengan cara membersamai mereka pada setiap tahapan-tahapannya.

2. Mengembangkan setiap bakat peserta didik dangan mempersiapkan prasarana yang beragam dan memadai.

3. Menuntun ide dan bakat peserta didik dengan memperbaiki dan menyempurnakannya dengan cara berfikir yang mandiri.

4. Bertahap dan berangsur dalam menerapkan unsur-unsur yang telah di sebutkan, sebagaimana di jelaskan oleh Al-Rãghib AlAshbahaniy dan Al-Baidhãwiy.

Hasil analisis dalam bidang attarbiyah sebagaimana di jelaskan oleh Abd. Rahman Al-Bãniy antara lain ialah :

1. Pendidik sesungguhnya ialah Allah subhãnahu wata'ãlã, karena sesungguhnya Ialah pencipta alam semesta, menciptakan fitrah manusia dan mengembangkannya, menuntun pertumbuhan dan tahapantahapannya dengan memperhatikan setiap apa yang di butuhkan hambaNya.

2. Sesungguhnya pendidikan praktis mestilah dituntun dengan aturan yang bersumber dari pada Allah subhãnahu wata'ãlã dan berpanduan kepada ketentuan hukumnya.

3. Pendidikan praktis bertujuan kepada pengenalan hamba kepada Penciptanya -Allah subhãnahu wata'ãlã- begitupun sasarannya.

4. Sesungguhnya tarbiyah membutuhkan langkah perencanaan teratur dan terikat antara satu dengan yang lainnya, antara setiap proses di bangun diatas satu sama lain, yang masing-masing tahapan didasarkan pada apa yang mendahuluinya. Begitupun halnya aktivitas pendidikan, berlangsung dengan aturan terorganisir dan terstruktur yang ianya senantiasa meningkat bersamaan dengan meningkatnya tahap kebutuhan peserta didik di setiap fasenya, bersesuaian dengan pertumbuhan dan kebutuhannya.

5. Selanjutnya aktivitas pendidik mengikuti perkembangan pertumbuhan manusia, sebagaimana ianya mengikuti setiap ketetapan hukum syariat Allah subhãnahu wata'âlã. (Abd. Rahman AlBãniy.1983.madkhal ilã at-tarbiyah fĩ dhau al-islam.Al-Maktab AlIslamiy. 13)

\section{Karakteristik Pendidikan Dalam Tinjauan Al-Quran dan As-Sunnah}

Tarbiyah ialah ilmu yang tertuju kepada manusia beserta aspek-aspek kehidupannya, yang mana ianya adalah pedoaman guna menghantarkan manusia secara perlahan menuju kesempurnaan dalam mengabdikan dirinya kepada Allah subhãnahu wata'ãlã dan mempersiapkan meraka untuk menjalani kehidupan yang bahagia dalam naungan syariat yang telah Allah subhãnahu wata'ãlã tetapkan untuk mereka.

Berkenaan dengan hal ini Imâm Fakhruddîn ar-Râzi dalam tafsirnya di surah al-Jumu'ah/62: 2; menyatakan bahwa: Kesempurnaan manusia diperoleh dengan mengetahui kebenaran serta kebajikan dan mengamalkan kebenaran dan kebajikan itu.

Maka, merujuk pada pernyatan di atas bahwasanya terdapat tujuan dalam tarbiyah menurut perspektif Al-Qur'an dan As-Sunnah, yaitu mengantarkan manusia kepada derajat sempurna dan mulia. Dan seorang muslim secara intuitif menyadari bahwasanya tidak ada kesempurnaan kecuali dalam beribadah kepada Allah subhãnahu wata'ãlã dan berpegang teguh 
terhadap syariat Allah subhãnahu wata'ãlã.

Sehingga, pengertian inilah yang lebih tepat, karena ianya mencakup seluruh sarana dan prasarana yang menghubungkan setiap tujuan manusia sampai titik akhir yang di harapkannya yaitu mencapai hakikat penghambaan yang sebenarnya kepadaAllah subhãnahu wata'âlã dan menjadi generasi yang terbaik dalam menjalankan estafeta kepemimpinan di atas muka bumi dengan menjadi hamba yang taat dan patuh kepadaNya.

Dan pada sisi inilah yang di abaikan oleh pemikir barat dalam memahami tarbiyah -pendidikan- sehingga membuatnya gagal dalam setiap upaya yang mereka lakukan terhadap pendidikan, di karenakan keterbatasan dan kurangnya pemahaman terhadap hakikat sebenarnya tentang realitas manusia, juga tujuan keberadaannya dan akhir dari sejarah kehidupan manusia itu sendiri.

Ada sebagian masyarakat memahami bahwasanya pendidikan itu hanya terbatas pendidikan jasmani, sebagian yang lain hanya memahami dari sisi mentalitas, sebagian yang lain hanya memahami pendidikan pada kebebasan dan manfaat individu yang tidak di batasi aturan dan kontrol apa pun, dan sebagian lain menganggap manusia hanyalah sebagai alat bagi kebutuhan sebagian komunitas yang tidak memiliki kebebasan, pendapat dan esensi apa pun.

Pendidikan Islam berbeda dengan pendidikan barat pada cakupan penekanan terhadap prinsip-prinsip agama yang abadi, aturan dan hukum yang memperkuat moralitas,perbedaan pemahaman tentang kebenaran, penolakan terhadap otonomi moral,dan penekanan pahala di akhirat sebagai motivasi perilaku bermoral. Dan inti dari perbedaan-perbedaan ini adalah keberadaan wahyu Ilahi sebagai sumber dan rambu-rambu pendidikan karakter dalam Islam.(Abdul Majid dan Dian Andayani, Pendidikan karakter, h.58 )

Maka dari pemahaman ini telah menggambarkan bahwasanya kurikulum pendidikan Islam itu sangat berbeda dari kurikulum lainnya, yang mana keistimewaannya ialah ianya memperlakukan manusia dari berbagai aspeknya, baik jiwa, akal mau pun ruhnya, ianya tidak mengabaikan salah satu dari tiga aspek tersebut dan tidak mengorbankan sisi yang lainnya, atau pun mengutamakan salah satu sisi dari sisi yang lainnya.(Ibn Qoyyim Al-Jauziyah. 1971.Tuhfah Al-Mudũd bi Ahkãm AlMaulũd.. 240-244)

Dan apabila terlintas pemahaman yang mengatakan bahwasanya tujuan pendidikan dalam Al-Qur'an dan AsSunnah ialah hanya terbatas hubungan makhluk dengan khaliknya melalui rutinitas ibadah tertentu tanpa memperhatikan sisi kehidupan yang lainnya, maka ini merupakan pemahaman yang keliru, karena ianya tidak akan sampai pada kehidupan yang baik dan layak sebagaimana yang di inginkan oleh syariat. Yang mana pemahaman ini terlahir dari ketidak fahaman terhadap Islam itu sendiri, juga tidak memahami cara dan karekteristik pendidikan dalam pandangan Al-Qur'an dan As-Sunnah. Bagaimana mungkin Islam mengabaikan kehidupan yang baik dan layak, padahal ianya memerintahkan manusia untuk berusaha, berpenghasilan dan menganjurkannya. Sesungguhnya tabiat Islam itu menganjurkan masyarakatnya untuk terus berusaha dan berdikari, karena dalam pergerakan terdapat kehidupan dan kekuatan, sedangkan berdiam diri menggambarkan kelemahan dan ketidakberdayaan.

Islam mencintai masyarakatnya untuk hidup dengan segenap kemampauan yang mereka miliki, berjuang dengan segala upaya dan kesungguhannya, memiliki usaha dan pekerjaan yang mereka tekuni dengan sungguh-sungguh, hingga tercapai kedaulatan yang mereka raih dengan segenap prestasi, mengibarkan kepemimpinan sejati dan mampu berdiri tegak penuh harga diri.

Maka, tujuan hidup menurut pandangan Islam ialah menghantarkan jiwa manusia pada amal perbuatan yang baik, meluruskan bakat, mewujudkan karya- 
karya yang profesional dan menghadirkan manusia yang handal dalam menjalani kehidupan.

Adapun ayat-ayat terkait ialah firman Allah subhãnahu wata'âlã :

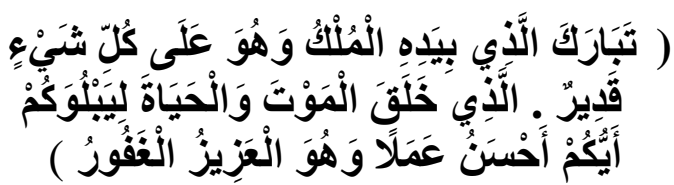

"Maha Suci Allah Yang di tanganNya-lah segala kerajaan, dan Dia Maha Kuasa atas segala sesuatu”.Yang menjadikan mati dan hidup, supaya Dia menguji kamu, siapa di antara kamu yang lebih baik amalnya.Dan Dia Maha Perkasa lagi Maha Pengampun".(QS. AlMulk 1-2)

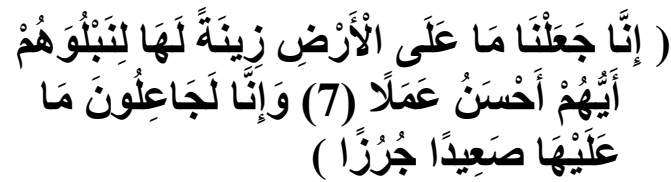

"Sesungguhnya Kami telah menjadikan apa yang ada di bumisebagai perhiasan baginya, untuk Kami menguji mereka, siapakah di antaranya yang terbaik perbuatannya.Dan Kami benarbenar akan menjadikan (pula) apa yang di atasnya menjadi tanah yang tandus lagi kering”. (QS. Al-Kahfi 7 -8)

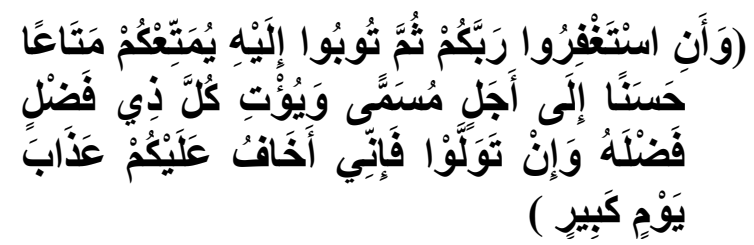

Dan hendaklah kamu meminta ampun kepada Tuhanmu dan bertaubat kepada-Nya. (Jika kamu mengerjakan yang demikian), niscaya Dia akan memberi kenikmatan yang baik (terus menerus) kepadamu sampai kepada waktu yang telah ditentukan dan Dia akan memberikan kepada tiap-tiap orang yang mempunyai keutamaan (balasan) keutamaannya. Jika kamu berpaling, maka sesungguhnya aku takut kamu akan ditimpa siksa hari kiamat”. (QS. Hud 3)

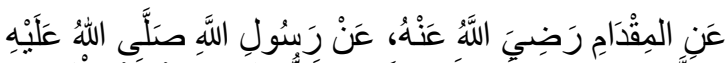

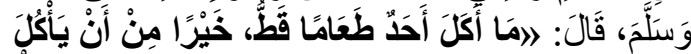

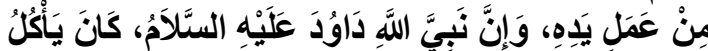

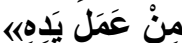

Diriwayatkan dari Miqdam radhiyallãhu 'anhu, dari Nabi Muhammad Shallãhu a'lahi wasallambersabda : "Tiada sesuap pun makanan yang lebih baik dari makanan hasil jerih payahnya sendiri. Sungguh, Nabi Daud AS itu makan dari hasil keringatnya sendiri"(HR. Bukhari)

Dapat di fahami dari uraian ayat-ayat Al-Qur'an dan hadits di atas, bahwasanya tarbiyah Islamiyah tidak mengabaikan perkara dalam mencapai kehidupan yang baik dan layak bagi manusia, karena sesungguhnya agama Islam itu menganjurkan masyarakatnya untuk selalu berusaha dan bekerja, bahkan pendidikan dalam Islam merupakan sebuah prinsip, dimana bagi seorang muslim akan diberikan ganjaran kebaikan apabila ia melaksanakannya dengan penuh tanggung jawab, dan sebaliknya akan mendapatkan hukuman jika ia melalaikannya.

Sebagaiman tertera dalam firman Allah subhãnahu wata'ãlã :

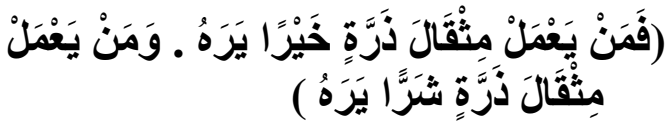

"Maka barang siapa mengerjakan kebaikan seberat zarrah, niscaya dia akan melihat (balasan)nya. Dan barang siapa mengerjakan kejahatan sebesar zarrah, niscaya dia akan melihat (balasan)nya". (QS. Al-Zalzalah 7 - 8)

Dan bahwasanya kedudukan seorang hamba di hadapan Allah subhãnahu wata'âlã di ukur dari sejauh mana amal kebaikan yang ia lakukan. Sebagaiman firman Allah subhãnahu wata'ãlã

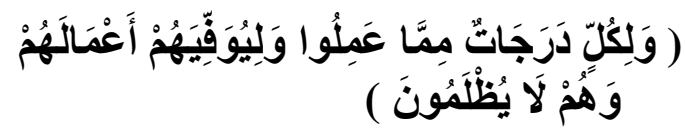

"Dan bagi masing-masing mereka derajat menurut apa yang telah mereka kerjakan dan agar Allah mencukupkan bagi mereka (balasan) pekerjaan-pekerjaan mereka 
sedang mereka tiada dirugikan”. (QS. AlAhqof 19)

Sehingga secara menyeluruh pendidikan Islam dalam hal ini memiliki karakteristik yang unggul dan dinamis. Pendidikan Islam mengandung nilai yang sacral dan suci, mempelajari segala hal untuk lebih mengenal sang pencipta Allah subhãnahu wata'ãlã.Manusia merupakan khalifatullah fil ardl yang berfungsi untuk beramal di dunia dan akan memperoleh hasilnya di akhirat.

Selain itu, Pendidikan Islam merupakan pendidikan yang komprehensif dan integral. Ajaran Islam yang dipahami bersama sebagaimana ianya dipahami oleh para ulama salafuna sholih dijadikan sebagai landasan berpikir serta bergerak dalam kehidupan sehari-hari. Ajaran Islam tidak dibatasi pedoman dalam segala dimensi gerak,ruang dan waktu. Agama Islam merupakan rahmat bagi seluruh alam. Ianya penyempurna daripada agamaagama sebelumnya, ajarannya senantiasa relevan dan sesuai hingga akhir zaman. Ajarannya mencakup seluruh aspek kehidupan manusia, ekonomi, sosial, budaya,politik, ilmu pengetahuan dan lainlainnya.

Pendidikan Islam adalah pendidikan yang dinamis. Ianya berjalan seiring dengan perkembangan yang ada dalam pola kehidupan masyarakat,dengan tetap menjaga nilai-nilai dan norma-norma keislaman sebagai pedomannya. Pendidikan Islam tidak antipati terhadap perkembangan yang ada ditengah masyarakat, begitupun dengan adanya perkembangan sains dan tekhnologi yang semakin canggih, hanya saja ianya sentiasa memberikan aturan dan batasan untuk membentengi diri dari hal-hal yang bertentangan dengan syariat agama. Sejalan dengan hal ini, maka Pendidikan Islam adalah pendidikan yang universal, sesuai pada setiap masa, zaman dan keadaan, dan dapat diterima oleh seluruh manusia. Ajaran Islam yang terkandung di dalam Al Quran memberikan segala yang dibutuhkan oleh umat manusia sepanjang zaman, dimanapun dan kapanpun.
Dan Pendidikan Islam adalah pendidikan yang kontinyu, tidak dikenal istilah "selesai belajar". Setiap muslim baik laki-laki maupun perempuan wajib belajar sepanjang hayat (long- life education). Bahkan tidak ada batasan waktu untuk terus mempelajari ilmu yang manfaat dunia dan akhirat. Bahkan Pendidikan Islam adalah pendidikan yang seimbang. Dalam ajaran Islam, umatnya dianjurkan untuk dapat mengoptimalkan berbagai potensi akal, ruh dan jasad secara seimbang. Dan segala sesuatu yang dilakukan dapat bermakna secara duniawi dan ukhrawi. Oleh karena itu, Pendidikan Islam adalah pendidikan yang tumbuh berkembang. Ilmu Pengetahuan yang telah dimiliki harus dapat dikembangkan dan memberikan manfaat untuk orang lain. Dan bahwa pendidikan Islam yang bersumber dari Al Quran dan Hadist menjadi tanggungjawab umatnya untuk dikembangkan dan diterapkan dalam berbagai bidang ilmu sesuai kebutuhan manusia dan berlandaskan pada kaidah ajaran Islam.

\section{KESIMPULAN}

Dalam kajian ini penulis telah merangkum beberapa kesimpulan penting di antaranya ialah :

1. Tujuan pendidikan dalam Al-Qur'an dan As-Sunnah ialah mengantarkan manusia kepada kesempurnaan, dan bahwasanya manusia tidak akan sampai pada kesempurnaan kecuali denganpenghambaannya kepada Allah subhãnahu wata'ãlãdan berpegang teguh pada syariatNya.

2. Pendidikan dalam Al-Qur'an dan AsSunnah tidak sebatas hanya hubungan makhluk dengan khaliknya melalui rutinitas ibadah tertentu tanpa memperhatikan sisi kehidupan yang baik dan layak, melainkan ianya mencakup semua aspek kehidupan manusia, karena sesungguhnya Islam adalah kehidupan dan kekuatan. Maka, selayaknya bagi masyarakat muslimuntuk selalu berusaha, berpenghasilan dan berdikari, karena Islam telah 
menggambarkanbahwasanya dalam pergerakan terdapat kehidupan dan kekuatan, sedangkan berdiam diri menggambarkan kelemahan dan ketidakberdayaan.

3. Sesunggungnya Islam adalah perumus pertama ilmu pendidikan, berbasis dari terbentuknya keluarga muslim yang baik yang mana orang tua adalah madrasah pertama bagi anak-anak sebelum mereka melangkah pada lingkup sekolah dan masyarakatnya. Maka, keluarga bertanggung jawab atas penyimpanganmoral dan sosial anak-anak, karena ianya adalah sentuhan pertama bagi anak-anak dalam menerima prinsip-prinsip moral dan dasar-dasar pendidikan. Sebagaimana pesan baginda Muhammad Shallãhu a'lahi wasallam:

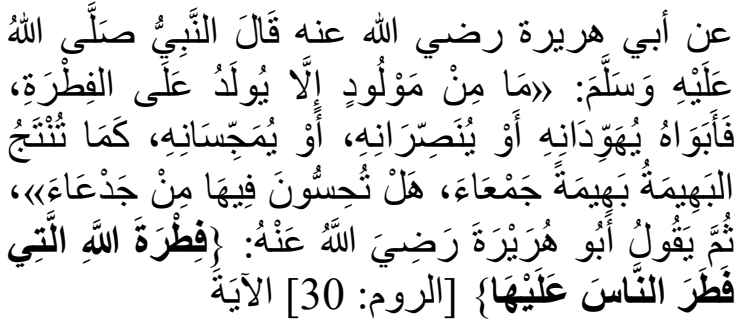

"Tiada bayi lahir yang lahir di atas fitrah. Lalu kedua orang tuanya lah yang menjadikannya orang Yahudi, atau Majusi atau Nasrani; seperti binatang yang melahirkan. Adakah kamu menemukan ada kecacatan? "Kemudian Abu Hurairah radhiyaallaahu 'anhu membaca firman Allah: Tetaplah pada fitrah Allah yang telah menciptakan manusia menurut fitrah itu. Tidak ada perubahan pada fitrah Allah. Itulah agama yang lurus. (QS. Ar-Ruum 30) (HR. Al-Bukhari)

\section{DAFTAR PUSTAKA}

Abd. Rahman Al-Bãniy.(1983). Madkhal ilã at-tarbiyah fĩ dhau al-islam. AlMaktab Al-Islamiy. Cet. 2. Tnp tmpt Abduh Faliyyah, Farũq. Abd Al-Fattãh, Ahmad.(Thn 2004). Mu'jam Mushthalahãt At-Tarbiyah lafdzan wa ishtilãhan. Percet Dãr Al-Wafã.AlIskamdariyya-Mesir. Tnp cet.
Abdul Majid, Dian Andayani, 2012, Pendidikan Karakter Perspektif Islam, Bandung: PT Remaja Rosdakarya .

Abũ Al-FidãIsmã'îl Ibn Katsĩr Al-Qorosy Al-Dimasyqiy.(thn2000/1420H). Tafsir al-quran al-adzĩm. Sãmĩ Muhammad salãmah (peneliti).Percetakan Dãr AlThoyyibah-KSA.Cet 2 .

Al-Badhãwiy. An-Wãru At-Tanzĩl wa Asrōru At-Ta'wĩl. Tnp thn\&cet.

Al-Harwiy Abu U'baid Al-Qōsim bin Salãm.(1396H). Gharĩb Al-Hadĩts. Muhammad Abd Al-Mu'ĩd Khãn (peneliti).Dãr Al-Kutub Al-Arabi.Cet 1.

Al-Jauhariy. Al-Shahhãh fĩ Al-Lughah. Dãr Shadir. Bairut. Tnp thn\&cet.

Al-Rãghib Al-Ashbahaniy. Mufradãt AlRãghib Al-Ashbahaniy. Cetakan Mushtafa Al-Babiy Al-Halbiy-Kiaro, Mesir. Tnp thn\&cet.

Ibn Fãris Abu Al-Husain Ahmad.(1423H/2002M).Mu'jam

Maqoyis Al-Lughah. Abdul Salam Muhammad Harun (peneliti). Ittihãd Al-Kutub Al-Arab.Tnp thn\&cet.

Ibn Mandzũr, Muhammad ibn Mukrom AlAfrĩqĩy Al-Mashriy. Lisãn Al'Arab.Percetakan Dār ShãdirBairut.Cet 1. Tnp thn.

Ibn Qoyyim Al-Jauziyah.(1971). Tuhfah Al-Mudũd bi Ahkãm Al-Maulũd.Abd. Al-Qōdir Al-Al-Arnauth (peneliti). Dãr Al-Bayãn-Damskus. Cet. 2.

Muhammad Abd Allah Darrãz.(1953). Kalimãt fĩMabãdi 'Ilm Al-Akhlãq. Cet. Al-'ãlamiyah. Tnp thn\&cet.

Samsul Nizar dan Zainal Efendi Hasibuan, Hadis Tarbawi: Membangun KerangkaPendidikan Ideal Perspektif Rasulullah, (Jakarta: Kalam Mulia, 2011)

Shãlih Abdul Allah humaid.Nandhrot AnNa'ĩm fĩ makãrim akhlãq Ar-Rosũl AlKarim.Percetakan Dãr Al-W hal ashĩlah.Jeddah-Saudi Arabiya. Cet 4. Tnp thn. 